\title{
Ongoing mumps outbreak in a student population with high vaccination coverage, Netherlands, 2010
}

J Whelan (jane.whelan@rivm.nl) ${ }^{1,2}$, R van Binnendijk ${ }^{1}$, K Greenland ${ }^{1,2}$, E Fanoy ${ }^{3,1}$, M Khargi $^{4}$, K Yap $^{5}$, H Boot $^{1}$, N Veltman $^{1}$, C Swaan $^{1}$, A van der Bij ${ }^{1}$, $H_{\text {de }}$ Melker $^{1}$, $S$ Hahné ${ }^{1}$

1. Centre for Infectious Disease Control, Rijksinstituut voor Volksgezondheid en Milieu (National Institute for Public Health and Environment, RIVM), Bilthoven, the Netherlands

2. European Programme for Interventional Epidemiology Training (EPIET), European Centre for Disease Prevention and Control (ECDC), Stockholm, Sweden

3. Municipal Health Service (MHS) “Midden-Nederland”, Zeist, the Netherlands

4. Municipal Health Service (MHS) "Hollands-Midden", Leiden, the Netherlands

5. Municipal Health Service (MHS), “Zuid-Holland West”, Zoetermeer, the Netherlands

Citation style for this article:

Citation style for this article: Whelan J, van Binnendijk R, Greenland K, Fanoy E, Khargi M, Yap K, Boot H, Veltman N, Swaan C, van der Bij A, de Melker H, Hahné S

Ongoing mumps outbreak in a student population with high vaccination coverage, Netherlands, 2010. Euro Surveill. 2010;15(17):pii=19554. Available online: http:// www.eurosurveillance.org/ViewArticle.aspx?Articleld=19554

This article has been published on 29 April 2010

Since December 2009, mumps incidence has increased in the Netherlands. As of 20 April 2010, 172 cases have been notified on the basis of laboratory confirmation or linkage to a laboratory-confirmed case. Of these, 112 were students, the majority of whom had been vaccinated $(81 \%)$. Although outbreaks in vaccinated populations have been described before, risk factors for exposure and susceptibility, and dose-dependent vaccine effectiveness in a student population of this nature are relatively unknown.

\section{Background}

Mumps has been a notifiable disease in the Netherlands since 2009. Notification criteria include at least one related symptom (acute onset of painful swelling of the parotid or other salivary glands, orchitis or meningitis) and laboratory confirmation of infection or an epidemiological link to a laboratory-confirmed case [1]. The measles-mumps-rubella (MMR) vaccine containing the Jeryl Lynn mumps virus strain was introduced in the Netherlands in 1987. Vaccination is recommended, with a two dose schedule at the age of 14 months and nine years. In 2007 and 2009, an epidemic (genotype D) occurred in a socio-geographically clustered, Dutch reformed protestant community with low vaccination coverage [2]. Nationally however, vaccine coverage with two doses has been consistently above 93\% [3]. Despite this, an outbreak of mumps occurred among vaccinated national and international students at a particular school in 2004 [4]. A resurgence of mumps has been observed in vaccinated populations in countries worldwide since 2004 [5].

\section{Descriptive epidemiology}

In the 11 months from January to November 2009, 65 cases of mumps were reported to the National Institute for Public Health and Environment (RIVM) in the Netherlands. Between 1 December 2009 and 20 April 2010, 172 notifications of mumps cases were received (Figure 1), of whom $24 \%$ became ill in late February (week 11) 2010. Seventy-nine of the cases were from the Municipal Health Service (MHS) Zuid-Holland West (including the city of Delft), 44 were from MHS HollandsMidden (including the city of Leiden) and accounted for the majority of cases in week 11, 11 were reported in MHS Utrecht, and an additional 38 cases were reported from other regions across the Netherlands. The median age was 21 years (range: four to 46 years) and $58 \%$ $(n=99)$ were male. Most of the patients had mild symptoms, but 14 (9\%) reported some complication, which in 12 cases was orchitis ( $12 \%$ of men). One person was hospitalised for one night due to severe symptoms but had no complications. Routinely collected notification data revealed that a large proportion of cases $(n=112$, $65 \%$ ) were students. A further 11 cases were contacts of students.

Twenty-seven student-cases (24\% of cases) reported attending a student party (attended by over 2,000

\section{FIGURE 1}

Mumps cases by week of onset of illness, the Netherlands, December 2009-April $2010(\mathrm{n}=172)$

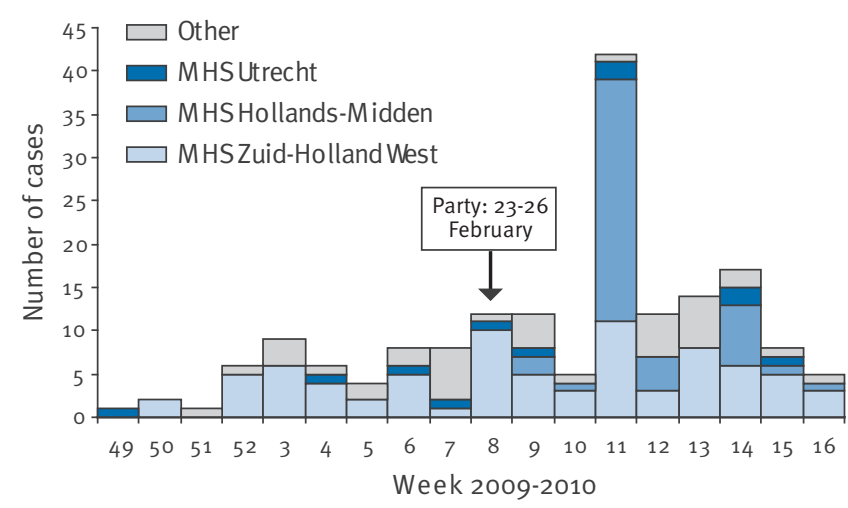

MHS: Municipal Health Service.

Report date: 20 April 2010. 
students) held in mid-February (week 8) over four days and nights in a building of the Leiden student's association. The students suspected this to be the source of infection. Given the incubation period of mumps is typically 16 to 18 days, this would coincide with the surge in cases seen in week 11 in MHS Hollands-Midden. Some attended the party for one night only (mainly students from Delft and Utrecht), but the majority from Leiden attended for three or four days and nights in succession. An outbreak investigation into risk factors for acquisition of mumps by the MHS in Leiden, Delft and Utrecht is currently underway in collaboration with the Centre for Infectious Disease Control of RIVM.

\section{Microbiological findings}

The clinical diagnosis of notified cases was laboratoryconfirmed by at least one method in $46 \%$ of cases $(n=79)$ : by detection of a mumps-specific IgM antibody response in $20 \%$ of cases $(n=32)$, by detection of mumps virus RNA in $30 \%(n=48)$, and/or by cultivation of mumps virus in $10 \%(n=16)$. Where there was no laboratory confirmation, an epidemiological link to a laboratory-confirmed case was established in $45 \%$ of cases $(n=78)$. Five cases did not meet notification criteria because they were linked epidemiologically to an index case, but laboratory confirmation of that index case was not established at the time of notification. The remaining ten cases reportedly met the notification

\section{TABLE}

Vaccination status of cases reported as students and others, The Netherlands, December 2009-April 2010 ( $\mathrm{n}=164$ )

\begin{tabular}{|c|c|c|c|c|c|c|}
\hline \multirow{2}{*}{ Vaccination status of respondents } & \multicolumn{2}{|c|}{ Not reported to be students } & \multicolumn{2}{|c|}{ Reported as students } & \multicolumn{2}{|c|}{ Total } \\
\hline & $n$ & $\%$ & $n$ & $\%$ & $n$ & $\%$ \\
\hline At least one dose & 29 & 50 & 85 & 81 & 114 & 70 \\
\hline 1 dose & 8 & 14 & 6 & 6 & 14 & 9 \\
\hline 2 doses & 21 & 36 & 77 & 73 & 98 & 60 \\
\hline 3 doses & 0 & 0 & 2 & 2 & 2 & 1 \\
\hline Vaccinated with unknown number of doses & 0 & 0 & 1 & 1 & 1 & 1 \\
\hline Unvaccinated & 29 & 50 & 20 & 19 & 49 & 30 \\
\hline Total & 58 & 100 & 106 & 100 & 164 & 100 \\
\hline
\end{tabular}

\section{FIGURE 2}

Mumps cases by age and vaccination status, the Netherlands, December 2009-April 2010 (n=172)

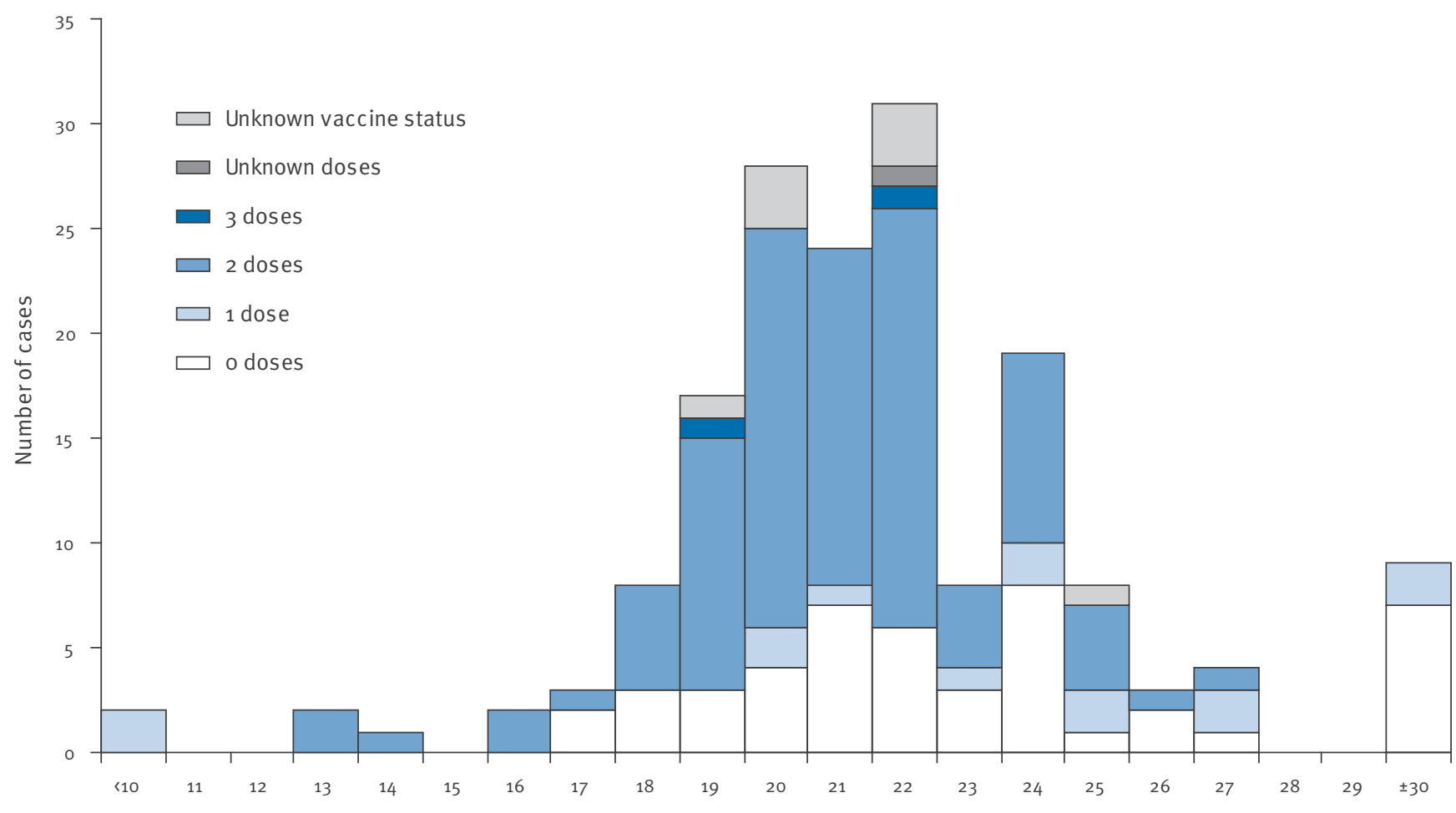


criteria, but reasons for notification were incomplete or missing $(n=6 \%)$. Genotyping of isolated mumps viruses revealed that the outbreak strain belonged to the $\mathrm{G}_{5}$ lineage.

\section{Vaccination status of cases}

Reported vaccination coverage among cases, particularly among the students, was high (Table). Of the 164 for whom vaccine status was known, 115 (70\%) were vaccinated and $100(61 \%)$ had received at least two mumps vaccinations. Among the 106 students for whom vaccine status was known, $85(81 \%)$ were vaccinated at least once, and 79 of them were vaccinated at least twice.

Age and vaccination status of cases are presented in Figure 2.

\section{Discussion}

Mumps outbreaks among vaccinated populations are reported world-wide [5-7]. Clinical attack rates are generally lower in vaccinated populations (indicating a protective effect), but there is growing evidence of waning immunity over time, [8-10] leading to secondary vaccine failure $[4,10-12]$. The majority of cases in this outbreak were students aged 18 to 24 years, of whom $73 \%$ had received at least two mumps vaccinations. The clustering of cases among students (in Leiden and to a lesser extent in Delft and Utrecht) suggests that intensive social contact during the four-day party may have facilitated transmission. Shared living facilities among members of the students' association, and the close contact environment of routine college life are also likely contributing risk factors $[13,14]$.

In accordance with recommendations from the World Health Organization [15], most countries now offer a two-dose vaccine schedule for mumps. In the Netherlands, all birth cohorts since 1982 have been offered two vaccine doses. Exceptionally, there is a suggestion that those born in 1986 and 1987 (now aged 23), were offered three doses of MMR at the age of 14 months, four years and nine years [16], but this remains to be confirmed. Dutch children are older when they receive the second vaccine dose (at age nine years) compared to those in the United Kingdom, the United States and Canada, where it is given at four to six years of age. Boosting of the immune response by circulating wildtype virus is unlikely as mumps has not been widespread in the Netherlands except for a restricted outbreak within the religious community a few years previously [2]. Primary vaccine failure is possible but a post-vaccination seroprevalence of $93.2 \%$ has been shown in children under the age of three years in the Netherlands [17]. In addition to the intensive social contact implicated in this outbreak, the fact that it occurred among the oldest vaccinated cohorts in the Netherlands who received two vaccine doses makes secondary vaccine failure more plausible.
Careful investigation will be required to establish the relationship between increasing age on the one hand, and incidence rates, severity and post-exposure disease susceptibility on the other. Comparison of preand post-exposure antibody titres in a longitudinal study could give clues about correlates for protection against mumps virus infection, as this is not well understood for persons who have received two doses of the mumps vaccine. Antigenic differences between the Jeryl Lynn vaccine strain (genotype $A$ ) and the viral strain in this and other outbreaks (genotype G) have also previously been implicated [11], but recent data suggests a good degree of serologic cross-immunity between Jeryl Lynn and other genotypes [18].

Current outbreak response measures concentrate on gathering good surveillance data, and students in the cities affected by this mumps outbreak who are not fully vaccinated (i.e. with two doses of MMR) are advised to complete their MMR vaccination. In response to an ongoing outbreak in the United States among a population of young adults (age 7-18 years) with a similar high vaccination coverage, public health officials in New York have been offering a third dose of MMR vaccine in some schools since January 2010 [12]. The lower incidence of mumps in the Netherlands among those born in 1986 who may have received three vaccine doses in childhood is certainly interesting in this respect, but further investigation is required to confirm this.

On assessment, the risk of a large national outbreak in the Netherlands is considered to be low because of high overall vaccine coverage and the clustered nature of student social life. Offering a third vaccine dose is not planned at present. With the cooperation of the municipal health services and the students' associations, we intend to conduct further research to better understand the risk factors associated with mumps exposure and susceptibility, and dose-related vaccine effectiveness.

\section{Acknowledgements}

We would like to thank patients, clinicians, staff of laboratories and of municipal health services, and students for their contribution to generating the information reported in this manuscript.

\section{References}

1. Parotitis epidemica: Bof (Mumps) B26. Bilthoven: National Institute for Public Health and the Environment (RIVM); 2009. [Accessed 12 April 2010]. Available from: http://www.rivm.nl/ cib/infectieziekten-A-Z/infectieziekten/Parotitis_epidemica/ index.jsp. Dutch.

2. Karagiannis I, van Lier A, van Binnendijk R, Ruijs H, Fanoy $E$, Conyn-Van Spaendonck M, et al. Mumps in a community with low vaccination coverage in the Netherlands. Eurosurveillance. 2010;12(13). pii:18901. Available from: http://www. eurosurveillance.org/ViewArticle.aspx?Articleld=18901 
3. van Lier E, Oomen P, Oostenburg M, Zwakhals S, Drijfhout I, de Hoogh P, et al. Vaccinatiegraad Rijksvaccinatieprogramma Nederland. Verslagjaar 2009. [National Immunisation Programme in the Netherlands. Annual Report 2009]. Bilthoven: National Institute for Public Health and the Environment (RIVM); 2009. Available from: http://www.rivm. nl/bibliotheek/rapporten/210021010.pdf

4. Brockhoff HJ, Mollema L, Sonder GJ, Postema CA, van Binnendijk RS, Kohl RH, et al. Mumps outbreak in a highly vaccinated student population, The Netherlands, 2004. Vaccine. 2010;9;28(17):2932-6.

5. Dayan GH, Rubin S. Mumps outbreaks in vaccinated populations: are available mumps vaccines effective enough to prevent outbreaks? Clin Infect Dis. 2008;47(11):1458-67.

6. Stein-Zamir C, Shoob H, Abramson N, Tallen-Gozani E, Sokolov I, Zentner G. Mumps outbreak in Jerusalem affecting mainly male adolescents. Euro Surveill. 2009;14(50). pii=19440. Available from: http://www.eurosurveillance.org/ViewArticle. aspx?Articleld $=19440$

7. Schwarz NG, Bernard H, Melnic A, Bucov V, Caterinciuc N, An der Heiden M, et al. Mumps Outbreak in the Republic of Moldova, 2007-2008. Pediatr Infect Dis ]. 2010 Mar 19. [Epub ahead of print].

8. Briss PA, Fehrs LJ, Parker RA, Wright PF, Sannella EC, Hutcheson $\mathrm{RH}$, et al. Sustained transmission of mumps in a highly vaccinated population: assessment of primary vaccine failure and waning vaccine-induced immunity. J Infect Dis. 1994;169(1):77-82.

9. Cohen C, White JM, Savage EJ, Glynn JR, Choi Y, Andrews N, et al. Vaccine effectiveness estimates, 2004-2005 mumps outbreak, England. Emerg Infect Dis. 2007;13(1):12-7.

10. Cortese MM, Jordan HT, Curns AT, Quinlan PA, Ens KA, Denning PM, et al. Mumps vaccine performance among university students during a mumps outbreak. Clin Infect Dis. 2008;46(8):1172-80.

11. Peltola H, Kulkarni PS, Kapre SV, Paunio M, Jadhav SS, Dhere RM. Mumps outbreaks in Canada and the United States: time for new thinking on mumps vaccines. Clin Infect Dis. 2007;45(4):459-66.

12. Centers for Disease Control and Prevention (CDC).

Update: Mumps Outbreak - New York and New Jersey, June 2009-January 2010. MMWR Morb Mortal Wkly Rep. 2010;12;59(5):125-9.

13. Whyte D, O'Dea F, McDonnell C, O'Connell NH, Callinan $\mathrm{S}$, Brosnan E, et al. Mumps epidemiology in the mid-west of Ireland 2004-2008: increasing disease burden in the university/college setting. Euro Surveill. 2009;14(16). pii=19182. Available from: http://www.eurosurveillance.org/ ViewArticle.aspx?Articleld $=19182$

14. Huang AS, Cortese MM, Curns AT, Bitsko RH, Jordan HT, Soud $\mathrm{F}$, et al. Risk factors for mumps at a university with a large mumps outbreak. Public Health Rep. 2009;124(3):419-26.

15. World Health Organisation. Mumps Virus Vaccines. Wkly Epidemiol Rec. 2007;82(7):51-60.

16. Inspectie voor de gezondheidszorg. [Inspectorate for Health]. Vaccinatietoestand Nederland per 1 januari 2003: Rapport. [Vaccination in the Netherlands as of 1 January 2003: Report]. The Hague: Staatstoezicht op de Volksgezondheid [State Supervision of Public Health]; 2004. Available at: http://www. rivm.nl/bibliotheek/rapporten/210021001.pdf

17. van den Hof S, Beaumont MT, Berbers GA, de Melker HE. Antibodies against mumps in The Netherlands as assessed by indirect ELISA and virus neutralization assay. Epidemiol Infect. 2003;131(1):703-9.

18. Rubin SA, Qi L, Audet SA, Sullivan B, Carbone KM, Bellini WJ, et al. Antibody induced by immunization with the Jeryl Lynn mumps vaccine strain effectively neutralizes a heterologous wild-type mumps virus associated with a large outbreak. J Infect Dis. 2008;198(4):508-15. 